\title{
Preparation of High-Transparency, Superhydrophilic Visible Photo-Induced Photocatalytic Film via a Rapid Plasma-Modification Process
}

\author{
Bing-Jyh Lu ${ }^{1}$ (D), Keng-Ta Lin ${ }^{2}$, Yi-Ming Kuo ${ }^{3}$ and Cheng-Hsien Tsai ${ }^{1, *(D)}$ \\ 1 Department of Chemical and Materials Engineering, National Kaohsiung University of Science and Technology, \\ Kaohsiung 807, Taiwan; 1101411103@nkust.edu.tw \\ 2 Office of General Affairs, National Kaohsiung University of Science and Technology, Kaohsiung 807, Taiwan; \\ lin2603@nkust.edu.tw \\ 3 Department of Optometry, Chung Hwa University of Medical Technology, Tainan 717, Taiwan; \\ yiming@mail.hwai.edu.tw \\ * Correspondence: chtsai@nkust.edu.tw; Tel.: +886-7-3814526 (ext. 15110); Fax: +886-7-3830674
}

Citation: Lu, B.-J.; Lin, K.-T.; Kuo, Y.-M.; Tsai, C.-H. Preparation of High-Transparency, Superhydrophilic Visible Photo-Induced Photocatalytic Film via a Rapid Plasma-Modification Process. Coatings 2021, 11, 784. https://doi.org/10.3390/ coatings 11070784

Received: 22 May 2021

Accepted: 23 June 2021

Published: 30 June 2021

Publisher's Note: MDPI stays neutral with regard to jurisdictional claims in published maps and institutional affiliations.

Copyright: (c) 2021 by the authors. Licensee MDPI, Basel, Switzerland. This article is an open access article distributed under the terms and conditions of the Creative Commons Attribution (CC BY) license (https:/ / creativecommons.org/licenses/by/ $4.0 /)$.

\begin{abstract}
In this study, different amounts of $\mathrm{SiO}_{2}$ nanoparticles $(7 \mathrm{~nm})$ were added to simultaneously reach high transmittance, high hardness, and high adhesion for $\mathrm{TiO}_{2}$ film prepared by the sol-gel method and coated on glass through a dip-coating technique. For the film to achieve self-cleaning, anti-fogging, superhydrophilicity, and visible photo-induced photocatalysis, $\mathrm{TiO}_{2}-\mathrm{SiO}_{2}$ film was modified via a rapid microwave plasma-nitridation process for efficient $\mathrm{N}$-doping by various $\mathrm{N}_{2-}$ containing gases $\left(\mathrm{N}_{2}, \mathrm{~N}_{2} / \mathrm{Ar} / \mathrm{O}_{2}, \mathrm{~N}_{2} / \mathrm{Ar}\right)$. Through nitrogen plasma, the content of $\mathrm{N}$ atom reached $1.3 \%$ with the ratio of $\mathrm{O} / \mathrm{Ti}$ atom being 2.04 . The surface of the thin films was smooth, homogeneous, and did not crack, demonstrated by the root mean square (RMS) roughness of film surface being 3.29-3.94 $\mathrm{nm}$. In addition, the films were composed of nanoparticles smaller than $10 \mathrm{~nm}$, with a thickness of about $100 \mathrm{~nm}$, as well as the crystal phase of the thin film being anatase. After the plasmanitridation process, the visible-light transmittance of $\mathrm{N}$-doped $\mathrm{TiO}_{2}-\mathrm{SiO}_{2}$ films was $89.7 \%$ (clean glass $=90.1 \%$ ). Moreover, the anti-fogging ability was excellent (contact angle $<5^{\circ}$ ) even without light irradiation. The degradation of methylene blue showed that the photocatalytic performance of $\mathrm{N}$-doped $\mathrm{TiO}_{2}-\mathrm{SiO}_{2}$ films was apparently superior to that of unmodified films under visible-light irradiation. Moreover, the pencil hardness and adhesion rating test of the thin films were $7 \mathrm{H}$ and 5B, respectively, indicating that the obtained coatings had great mechanical stability.
\end{abstract}

Keywords: plasma modification; self-cleaning; anti-fogging film; superhydrophilic photocatalyst; nitridation

\section{Introduction}

Titanium oxide $\left(\mathrm{TiO}_{2}\right)$ is a very important material due to its multifunctional application in photocatalysis, hydrophilic or hydrophobic material, gas sensors, biosensors, photovoltaic cells, photochromic/electrochromic/optical devices, corrosion protection, and bactericide [1-3]. Superhydrophilic and self-cleaning $\mathrm{TiO}_{2}$ film on glass can be used to decompose oily stains or air pollutants, which could have promising potential applications in industry. Moreover, through the production and modification of light-sensitive $\mathrm{TiO}_{2}$ thin films, mirrors or windows with high performance of self-cleaning and anti-fogging functions could be achieved [4-6].

$\mathrm{TiO}_{2}$ has a high refractive index ( $n=2.52$ for anatase; 2.76 for rutile), resulting in poor transmittance, no adsorption bands in the visible wavelengths, and the formation of white surface coatings $[7,8]$. Hence, refractive index grading at the interface of two materials is required for reaching efficient transmission of a normal-incident wave for some particular wavelengths. Since $\mathrm{SiO}_{2}$ provides a refractive index that is intermediate between that of air (index of refraction, $n=1)$ and that of glass $(n=1.55), \mathrm{SiO}_{2}(n=1.46)$, it is generally used 
in solar cells of silicon-based thin film [9]. A previous study proposed mixing $\mathrm{TiO}_{2}$ and $\mathrm{SiO}_{2}$ for the promotion of various unique purposes, including superhydrophilic and selfcleaning functions under UV-light illumination [10]. The results revealed that the surface oxygen vacancies are saturated by $\mathrm{OH}$ groups, leading to a superhydrophilic surface [11]. Hence, adding $\mathrm{SiO}_{2}$ nanoparticles into $\mathrm{TiO}_{2}$ sol-gel to elevate the transmittance of film was carried out in this study.

Modified $\mathrm{TiO}_{2}$ photocatalysts can be produced by the deposition of metal $(\mathrm{Cu}, \mathrm{Ag}$, $\mathrm{Pt}, \mathrm{Au}, \mathrm{Wu}, \mathrm{Pd}$ ) or the doping of non-metal elements (N, P, S, C, F). The photocatalysis can be achieved under ultraviolet or visible-light irradiation, which highlights the demand for them as usable materials within the energy and environmental sectors [2,12-16]. The production of visible-light photocatalysts can lower the threshold energy of photoexcitation, and then apparently enhance the utilization of solar energy. The doping of various elements, particularly with $\mathrm{N}$, has been carried out in several studies [17-19]. $\mathrm{N}$-doped $\mathrm{TiO}_{2}$ photocatalysts can be synthesized via gas-phase or liquid-phase reactions, including the solgel method, chemical treatment of bare oxide, or high-temperature oxidation $[17,18,20,21]$. However, the plasma $\mathrm{N}$-doping technique provides a dry and rapid process.

The production of hydrophilic $\mathrm{TiO}_{2}$ photocatalyst film has been demonstrated through numerous approaches: radio-frequency magnetron sputtering, electron beam evaporation, and the sol-gel method accompanied by spin-coating or dip-coating [22-25]. Furthermore, the photocatalytic activity of $\mathrm{TiO}_{2}$ thin films doped with nitrogen can be utilized to form $\mathrm{TiO}_{2-x} \mathrm{~N}_{\mathrm{x}}$ photocatalysts via sputtering at low pressure, heating in an $\mathrm{NH}_{3}$-contained atmosphere, oxidative annealing of TiN, and direct high-temperature nitridation [26]. As a result of plasma-nitridation, it is a relatively simple and rapid process. Ti-N bonds and oxygen vacancies in the $\mathrm{TiO}_{2}$ films were formed by using a $13.56 \mathrm{MHz}$ cathodic magnetron plasma at 30-100 W, 5 Pa for 5 min [26]. For an $\mathrm{N}-\mathrm{TiO}_{2} / \mathrm{CNT}$ electrode, nitrogen-doped $\mathrm{TiO}_{2}$ was previously synthesized by plasma-enhanced atomic layer deposition on carbon nanotubes to enhance the specific capacity [27].

Simultaneously achieving high transparency/adhesion, superhydrophilicity, and visible photo-induced photocatalysis for the $\mathrm{TiO}_{2}$-based catalysts is exceedingly difficult. Due to the refractive index of $\mathrm{TiO}_{2}$ film/glass and the use of additives for modifying the catalyst, the combined interaction apparently decreases the transmittance of films. Hightransparent, superhydrophilic, visible photo-induced photocatalytic N-doped $\mathrm{TiO}_{2}-\mathrm{SiO}_{2}$ nano film on glass has received scarce attention within the literature, and thus is one of the focal points of the current study.

\section{Materials and Methods}

\subsection{Experimental Materials}

Ti-containing gel was prepared by first mixing acetylacetone $\left(\mathrm{AcAc}, \mathrm{CH}_{3} \mathrm{COCH}_{2} \mathrm{COCH}_{3}\right.$, $98 \%$, Fluka ${ }^{\circledR}$, Milwaukee, WI, USA) and tetraisopropoxide (TTIP, Ti $\left[\mathrm{OCH}\left(\mathrm{CH}_{3}\right)_{2}\right]_{4}, 99.8 \%$, Acros ${ }^{\circledR}$, Rochester, NY, USA) and then adding ethanol (EtOH, $\mathrm{C}_{2} \mathrm{H}_{5} \mathrm{OH}, 99.5 \%$, Shimakyu Pure Chemicals, Samut Sakhon, Thailand), hydrochloric acid ( $\mathrm{HCl}, 37 \%$, Nihon Shiyaku Reagent, Taipei, Taiwan), and $\mathrm{H}_{2} \mathrm{O}$ with a TTIP/AcAc/EtOH/HCl/ $\mathrm{H}_{2} \mathrm{O}$ molar ratio of 1:5:110:0.024:5.4. The molar concentrations of AcAc, TTIP, EtOH, $\mathrm{HCl}$, and $\mathrm{H}_{2} \mathrm{O}$ were 0.123, $0.615,13.53,0.003$, and $0.664 \mathrm{M}$, respectively. The solution was stirred for $3 \mathrm{~h}$ at $50^{\circ} \mathrm{C}$. Then, varying amounts of silica gel $\left(\mathrm{SiO}_{2}\right)$ nanoparticles $(7 \mathrm{~nm}$, Sigma-Aldrich, St. Louis, MO, USA) $(0,0.1,1,3 \mathrm{wt} . \%)$ were added to the sol-gel solution and stirred for $1 \mathrm{~h}$ to adjust the refractive index, as well as to reach the highest transmittance of film on the glass.

\subsection{Method}

The cleaning procedure of glass substrate $(1.1 \mathrm{~mm}$ thick, 76.2 by $25.4 \mathrm{~mm})$ was carried out first. The processes are as follows: ultrasonic shock in detergent solution for $20 \mathrm{~min}$ by an ultrasonic cleaner ( $400 \mathrm{~W}, 40 \mathrm{k} \mathrm{Hz}$, Delta DC400H, Delta Ultrasonic Co. Ltd., New Taipei City, Taiwan); deionized (DI) water flushing; ultrasonic shock in DI water for $20 \mathrm{~min}$; ultrasonic shock in methanol/ $\mathrm{HCl}(v / v=250: 250 \mathrm{~mL})$ solution for $20 \mathrm{~min}$, followed by 
DI water flushing. Then, the $\mathrm{TiO}_{2} / \mathrm{SiO}_{2}$ films on dry glass were applied via dip-coating technology at various withdrawal speeds (WS $=5,8,10,20,40 \mathrm{~mm} / \mathrm{s}$ ) to examine the effects on transmittance, adhesion, and hardness of the films on glass. Consequently, the prepared thin film was calcined by a furnace (in air, $2.3 \mathrm{~kW}$, Tender F-12, TenDer Co. Ltd., Kaohsiung, Taiwan) at $500{ }^{\circ} \mathrm{C}$ for $1 \mathrm{~h}$ with a heating rate of $2{ }^{\circ} \mathrm{C} / \mathrm{min}$ for transforming amorphous crystallization into the anatase phase.

To induce the self-cleaning ability of the film at visible light, the sensitive photocatalyst thin films with high transmittance and superhydrophilic attributes were modified by Ndoping the film via the microwave (MW) plasma-nitridation procedure using different reaction gases, including $\mathrm{N}_{2}, \mathrm{~N}_{2} / \operatorname{Ar}(4.7 \%) / \mathrm{O}_{2}(2 \%)$, and $\mathrm{N}_{2} / \operatorname{Ar}(6.7 \%)$ at a total flow rate of $12 \mathrm{~L} / \mathrm{min}\left(\mathrm{N}_{2}\right.$ is balanced gas) and an applied power of $900 \mathrm{~W}$ with a nitridation temperature of $500{ }^{\circ} \mathrm{C}$ for $1 \mathrm{~min}$. The pressure used in the MW plasma system during plasma-nitridation process was at atmospheric pressure. Table 1 presents the parameters and conditions of sample preparation in this study.

Table 1. Parameters and conditions of sample preparation.

\begin{tabular}{cc}
\hline Parameter & Conditions \\
\hline Addition of $\mathrm{SiO}_{2}$ nanoparticles (wt. $\left.\%\right)$ & $0,0.1,1,3$ \\
Withdrawal speed (mm/s) & $5,8,10,20,40$ \\
Gas compositions for plasma-nitridation & $\mathrm{N}_{2}, \mathrm{~N}_{2} / \operatorname{Ar}(4.7 \%) / \mathrm{O}_{2}(2 \%), \mathrm{N}_{2} / \operatorname{Ar}(6.7 \%)$ \\
\hline
\end{tabular}

The $2.45 \mathrm{GHz}$ microwave (MW) plasma apparatus was applied to modify the thin films. The general scheme of the system is similar to the previous study [28]. The plasma system was assembled with a commercially available magnetron (YJ-1600, National Electronics, La Fox, IL, USA), with a stationary power of $5 \mathrm{~kW}$ (maximum) and operated in continuouswave mode by passing microwaves through a circulator and a waveguide with a three-stub tuner, then reaching a cavity. An arc was used to ignite the plasma. A quartz tube reactor with a diameter of $2.9 \mathrm{~cm}$ intersected the waveguide (ASTEX WR340, MKS, Wilmington, MA, USA), and a resonator was placed perpendicular to it.

A glass dish was used for the photocatalytic experiments. The dish was cleaned by using DI water and ethanol solution, separately, with an ultrasonic oscillator for $30 \mathrm{~min}$ at room temperature. Then, the $\mathrm{SiO}_{2}-\mathrm{TiO}_{2}$ film/glass was located at the bottom of dish. The photocatalytic performance of the samples was assessed by adding $15 \mathrm{~mL}$ methyl blue (MB) (15 ppm) solution to the dish under visible light (Philips, T5-6WA, max. peak at $610 \mathrm{~nm}$, Amsterdam, The Netherlands). The effect of $\mathrm{N}$-doping on the catalysis performance of methylene blue via visible photo-induced process was examined and discussed.

\subsection{Analytical Methods}

The transmittance of the produced $\mathrm{TiO}_{2} / \mathrm{SiO}_{2}$ thin film was measured by using a UV-Vis spectrophotometer between 400 and $800 \mathrm{~nm}$ (Perkin Elmer/Lambda 35, Waltham, MA, USA). The thickness, morphology, and topology of thin films were characterized by scanning with an electron microscope (SEM, S3000N, Hitachi, Krefeld, Germany). The crystal structure of the synthesized $\mathrm{TiO}_{2}-\mathrm{SiO}_{2}$ film was determined using X-ray diffraction (XRD, RINT-2000, Rigaku, Austin, TX, USA) with $\mathrm{CuK} \alpha$ radiation in the scan range of $15^{\circ}$ to $85^{\circ}(2 \theta)$. The superhydrophilic capacity of films was examined by a contact-angle analyzer (Digidrop/R\&D, GBX, Dublin, Ireland). The roughness of films was analyzed by an atomic force microspore (AFM, NanoMan NS4 + D3100, Digital Instruments, Bresso, Italy). In the glow discharge zone, an optical emission spectrometer (OES, Ocean Optics, HR 4000CG, Kent, UK) was used to detect the active species involved in the plasma-nitridation process. 


\section{Results and Discussion}

\subsection{The Effects of $\mathrm{SiO}_{2}$ Addition and Withdrawal Speeds \\ 3.1.1. Average Transmittance}

After the cleaning procedure of glass substrate, the average transmittance of dry glass was $90.5 \%$ for the visible light region between 400 and $800 \mathrm{~nm}$. Then, $\mathrm{TiO}_{2}$ thin films were prepared by the gel prepared from the TTIP/AcAc/EtOH/HCl $/ \mathrm{H}_{2} \mathrm{O}$ solution via the dip-coating process. As a result, the average transmittance of double-sided $\mathrm{TiO}_{2}$ film/glass (without $\mathrm{SiO}_{2}$ addition) was apparently reduced. At a $5 \mathrm{~mm} / \mathrm{s}$ withdrawal speed (WS), the average transmittance was only $68.3 \%$. When WS was increased from 8 to $40 \mathrm{~mm} / \mathrm{s}$, the average transmittance was between $71.6 \%$ and $72.5 \%$ (Figure 1), significantly lower than that of original glass due to the high refractivity of $\mathrm{TiO}_{2}$ ( $n=2.52$ for anatase; 2.76 for rutile) compared to that of glass $(n=1.55)$ with a low surface roughness, which led to a reduction in transmittance for visible light.

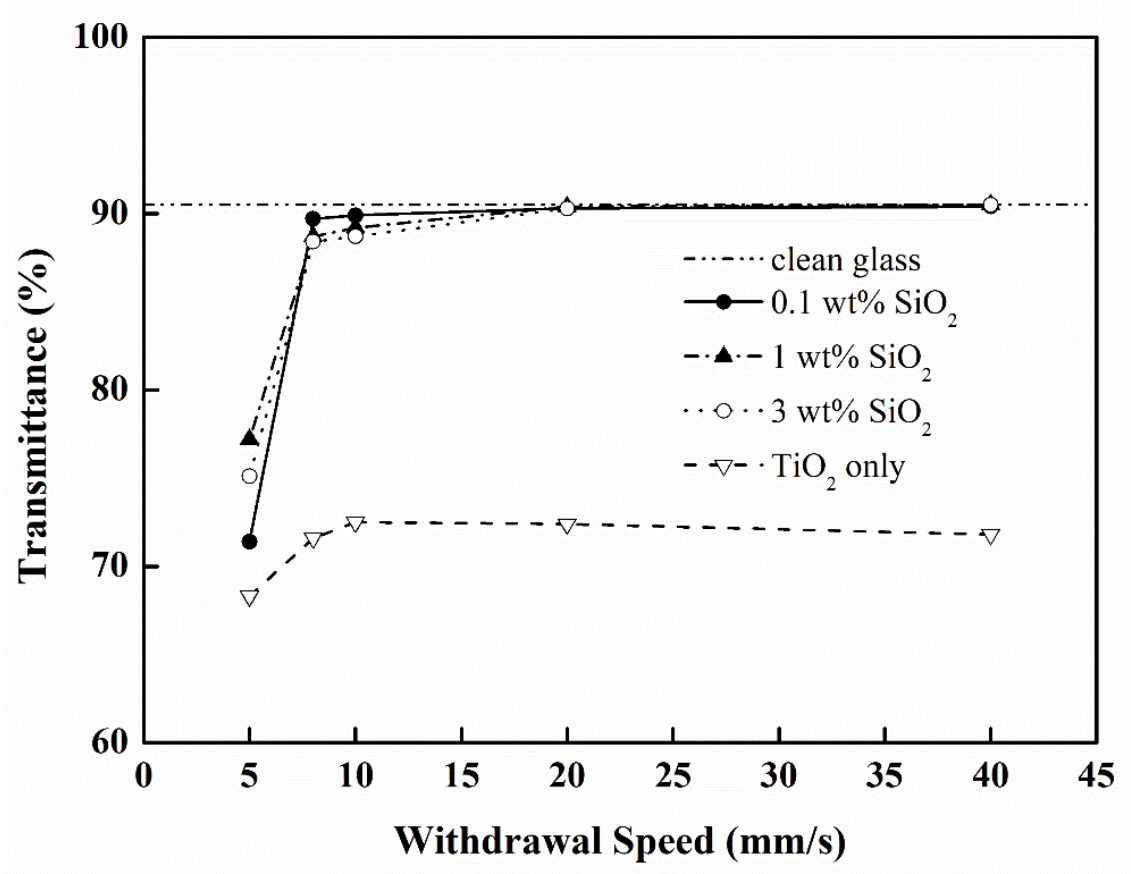

Figure 1. The transmittance of $\mathrm{TiO}_{2}$ film/glass with the addition of various amounts of $\mathrm{SiO}_{2}$ and different withdrawal speeds.

In order to elevate the transmittance of $\mathrm{TiO}_{2}-\mathrm{SiO}_{2}$ thin films, the nanoparticles of $\mathrm{SiO}_{2}$ $(0.1 \sim 3 \mathrm{wt} . \%)$ were added to the $\mathrm{TiO}_{2}$ gel. It is a similar technique with the production of anti-reflection optical film by adding the material of a lower index of refraction [29]. When the additional amount of $\mathrm{SiO}_{2}$ was in the range of $0.1 \sim 3 \mathrm{wt} . \%$, the average transmittances were significantly higher than those lacking the additional $\mathrm{SiO}_{2}(71.6 \%)$; a secondary result yielded a slight increase from increasing the withdrawal speed from $8 \mathrm{~mm} / \mathrm{s}$ to $40 \mathrm{~mm} / \mathrm{s}$ (Figure 1). The high visible-light transmittance $(88.0 \%$ to $90.6 \%$ ) of as-prepared film/glass could be achieved ( $90.5 \%$ for clear glass) when $\mathrm{SiO}_{2}$ nanoparticles were added; this new value was higher than those without the addition of $\mathrm{SiO}_{2}$ due to the reduction of the index of refraction. In addition, a higher withdrawal speed led to an increase of either film thickness or roughness, resulting in higher transmittance. Due to the higher transmittance for $0.1 \mathrm{wt} . \%$ added $\mathrm{SiO}_{2}$ than that for other amounts of added $\mathrm{SiO}_{2}$ at a withdrawal speed of $8 \sim 40 \mathrm{~mm} / \mathrm{s}$, an additional amount of $\mathrm{SiO}_{2}$ was fixed at $0.1 \%$ for the subsequent experiments. 


\subsubsection{Superhydrophilic Characteristics}

The angle of contact $(\theta)$ was about $10^{\circ}$ for the glass substrate after cleaning procedures. However, it was easily dirtied when absorbing the air pollutants or organics which existed in the atmospheric environment. When the $\mathrm{TiO}_{2}$ film was coated on the glass, $\theta$ decreased from $18^{\circ}$ to $7^{\circ}$ when the withdrawal speed was reduced from 40 to $5 \mathrm{~mm} / \mathrm{s}$ due to the elevation of the roughness of the surface, leading to an increase in hydrophilicity [30]. After 20 min of UV radiation, the angle of contact could decrease to under $5^{\circ}$, producing a superhydrophilic property of the film. However, $\theta$ reverted to its original status after $24 \mathrm{~h}$ of storage time in the dark.

When factoring in the addition of $\mathrm{SiO}_{2}, \theta$ decreased with the increase in the $\mathrm{SiO}_{2}$ addition, the decrease in withdrawal speed, and the UV irradiation time. At $0.1 \% \mathrm{SiO}_{2}$, $\theta$ decreased from $10^{\circ}$ to $5^{\circ}$ by decreasing WS from $40 \mathrm{~mm} / \mathrm{s}$ to $5 \mathrm{~mm} / \mathrm{s}$ under the condition of no UV irradiation (Figure 2) due to the elevation of roughness. Moreover, after UV irradiation for $20 \mathrm{~min}, \theta$ decreased to $1.5^{\circ} \sim 5^{\circ}$ (Figure 2a), achieving superhydrophilic and anti-fogging properties, as well as reverting to its original status after $24 \mathrm{~h}$ of storage time in the dark (Figure $2 b$ ). Furthermore, when the addition of $\mathrm{SiO}_{2}$ was increased from $0.1 \mathrm{wt} . \%$ to $3 \mathrm{wt} . \%, \theta$ only decreased $1 \sim 3^{\circ}$ due to similar roughness [31].
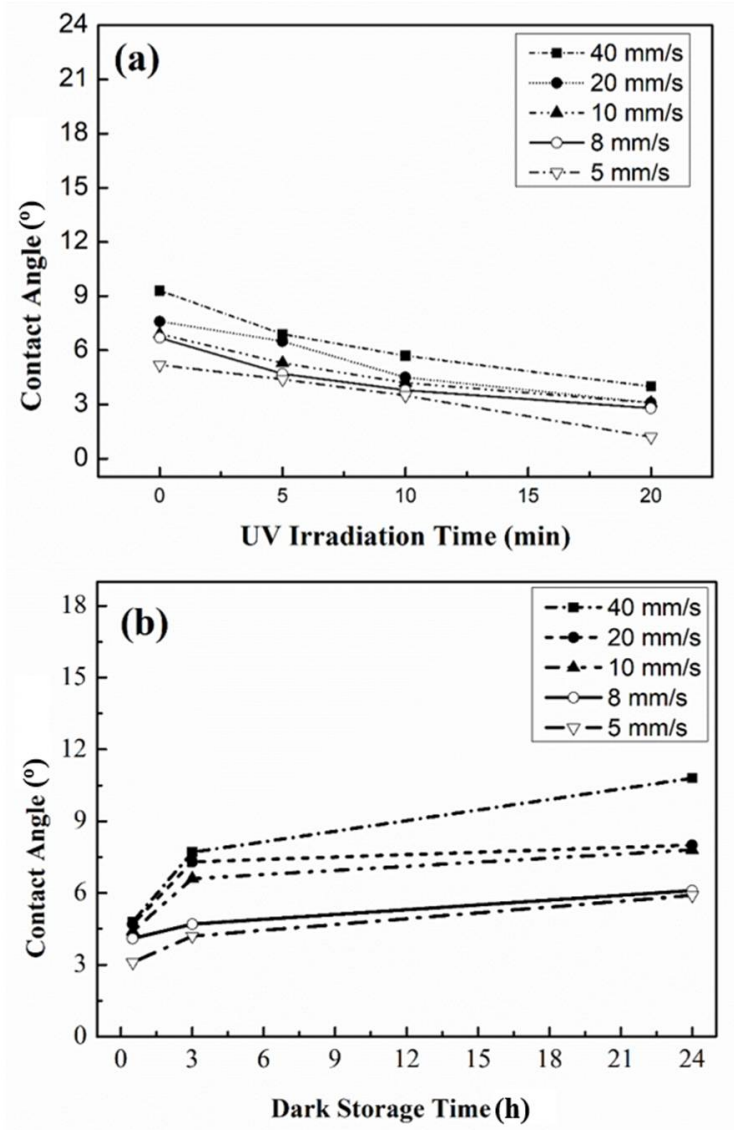

Figure 2. Surface contact angle of $\mathrm{TiO}_{2}-\mathrm{SiO}_{2}(0.1 \%)$ film (a) at various withdrawal speeds and UV irradiation times, and (b) the effect of storage time in the dark.

\subsection{Thickness, Morphology, and Topography of $\mathrm{TiO}_{2}-\mathrm{SiO}_{2}$ Films}

Figure 3 shows the profile and thickness of the $\mathrm{TiO}_{2}$ film at $\mathrm{SiO}_{2}=0.1 \mathrm{wt} . \%$. The faster withdrawal speed in the dip-coating process led to a thicker film [32]. The thickness of the thin film was only 70,90, and $110 \mathrm{~nm}$ at withdrawal speeds of 5,8 , and $10 \mathrm{~mm} / \mathrm{s}$, respectively. 

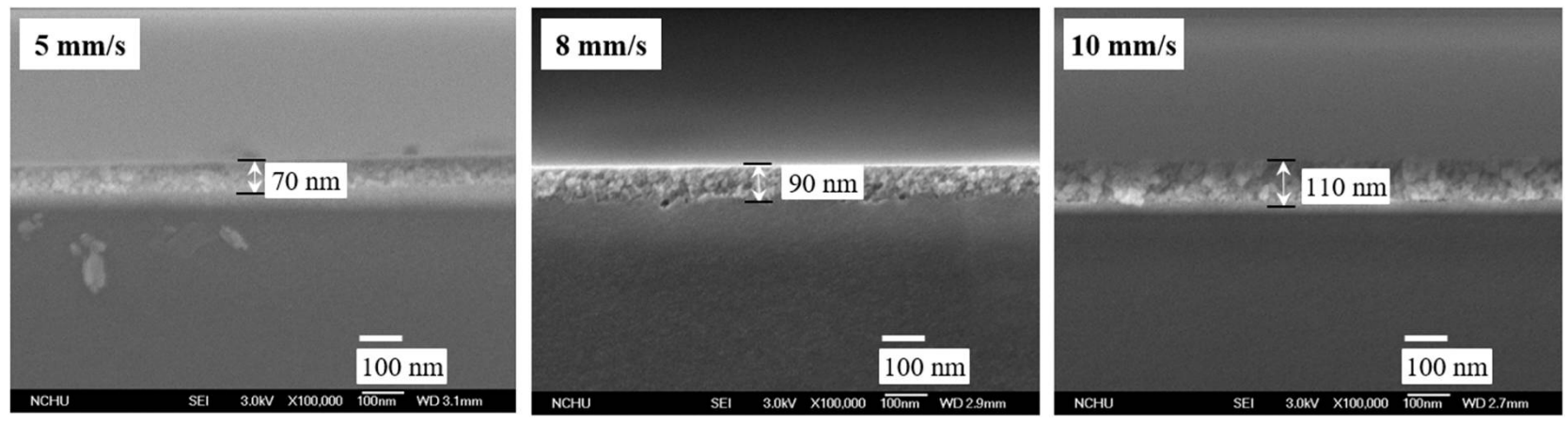

Figure 3. Thickness of $\mathrm{TiO}_{2}-\mathrm{SiO}_{2}(0.1 \%)$ films prepared at various withdrawal speeds $(\mathrm{SEM} \times 100,000)$.

From the morphology analysis, SEM images (Figure 4) showed that the films comprised well-distributed nanoparticles and the primary particle size was uniform and smaller than $10 \mathrm{~nm}$. As the various withdrawal speeds increased, the particle size and porosity gradually became smaller, resulting in the roughness being reduced (Figure 4). The surface of the films was exceptionally smooth, and the nanoparticles were arranged compactly. Moreover, there was no aggregation or agglomeration of particles found, even after sintering at $500{ }^{\circ} \mathrm{C}$.

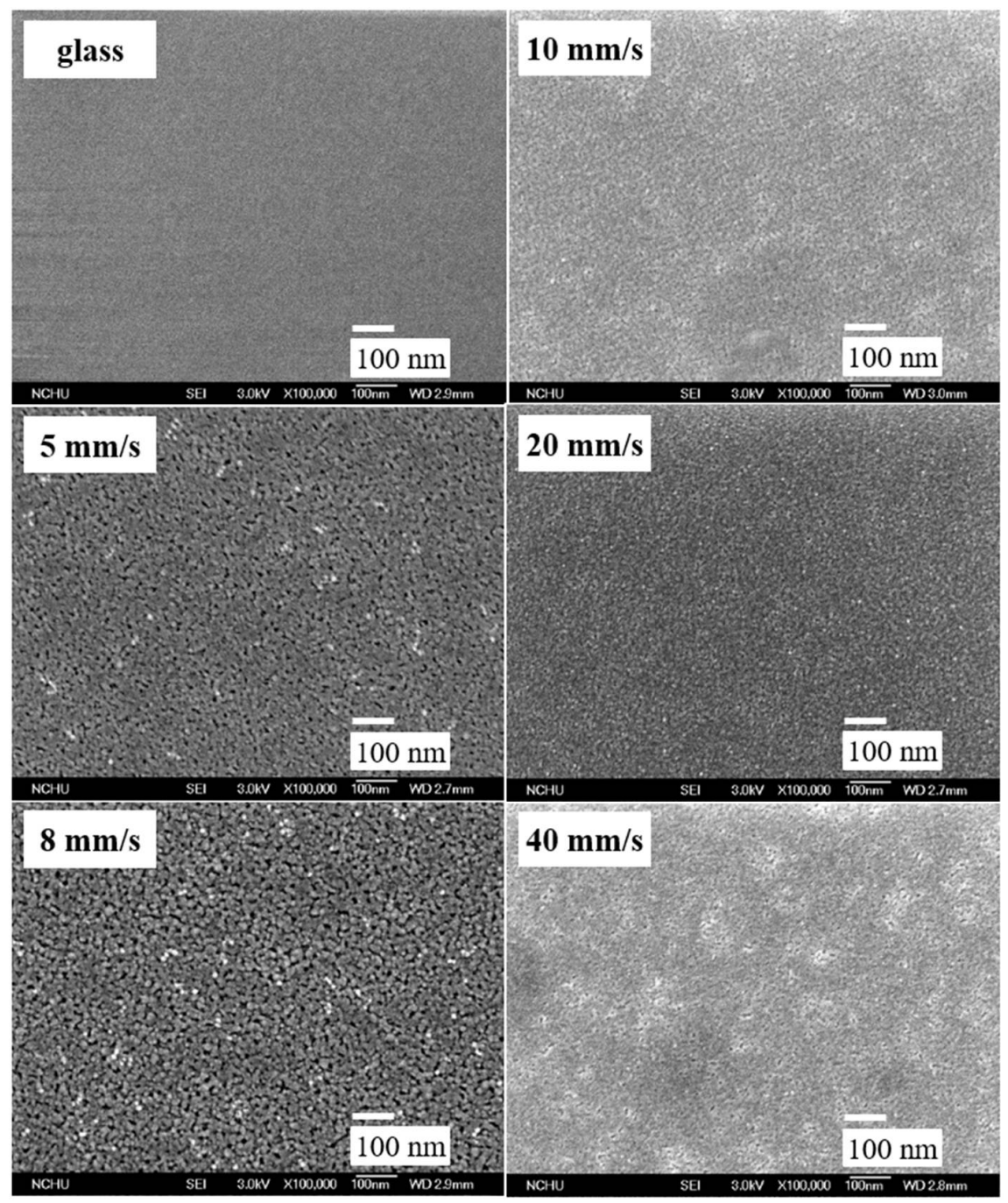

Figure 4. Morphology of $\mathrm{TiO}_{2}-\mathrm{SiO}_{2}(0.1 \%)$ films prepared at various withdrawal speeds $(\mathrm{SEM} \times 100,000)$. 
Based on the XRD patterns of $\mathrm{TiO}_{2}-\mathrm{SiO}_{2}$ /glass substrate (Figure 5), the amorphous $\mathrm{TiO}_{2}$ structure existed either in the as-prepared film/glass or after annealing at $200{ }^{\circ} \mathrm{C}$. After annealing at $500{ }^{\circ} \mathrm{C}$, characteristic peaks of main anatase $\mathrm{TiO}_{2}$ (JCPDS No. 21-1272) without rutile crystal structures were observed.

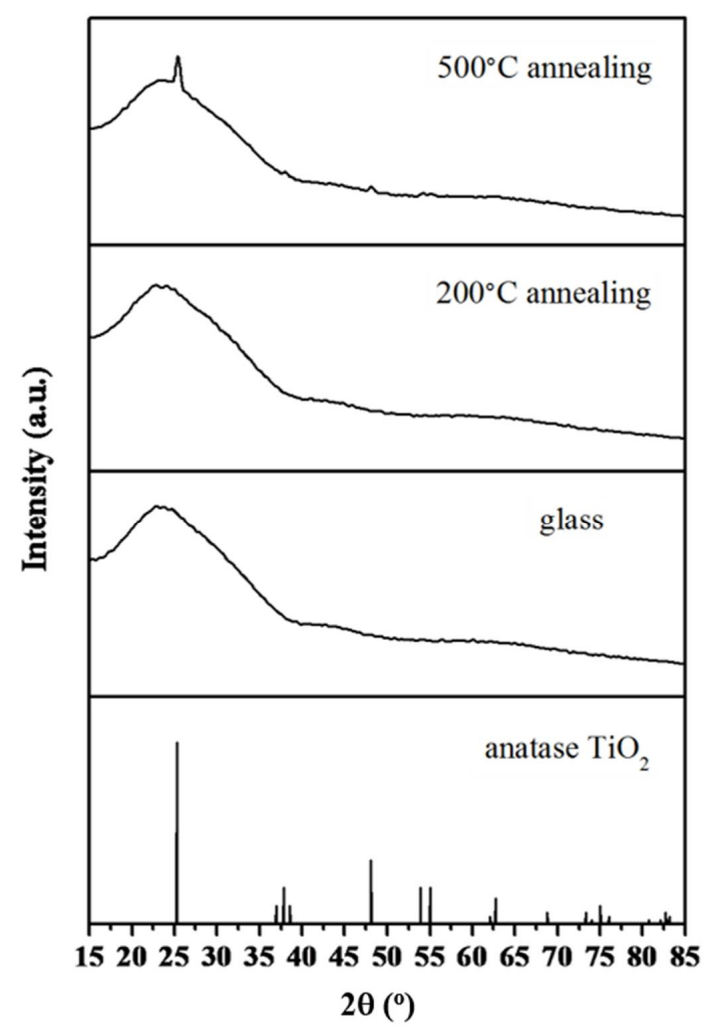

Figure 5. Features of the $\mathrm{XRD}$ pattern for glass and $\mathrm{TiO}_{2}-\mathrm{SiO}_{2}$ film annealing at $200{ }^{\circ} \mathrm{C}$ and $500{ }^{\circ} \mathrm{C}$.

The analysis of the atomic force microscope indicated that the root mean square roughness of the surface was only $0.25 \mathrm{~nm}$ for clean glass. After the coating of $\mathrm{TiO}_{2}$ with $0.1 \mathrm{wt} . \% \mathrm{SiO}_{2}$, excluding the film thickness, the roughness was affected by withdrawal speed, reaching $5.73 \mathrm{~nm}$ at a WS of $5 \mathrm{~mm} / \mathrm{s}$, then decreasing to $0.61 \mathrm{~nm}$ at a WS of $40 \mathrm{~mm} / \mathrm{s}$ (Table 2).

Table 2. RMS roughness of surface of $\mathrm{TiO}_{2}-\mathrm{SiO}_{2}(0.1 \%)$ films prepared at various withdrawal speeds.

\begin{tabular}{ccccccc}
\hline $\begin{array}{c}\text { Withdrawal Speed } \\
(\mathbf{m m} / \mathbf{s})\end{array}$ & $\mathbf{5}$ & $\mathbf{8}$ & $\mathbf{1 0}$ & $\mathbf{2 0}$ & $\mathbf{4 0}$ & Glass \\
\hline RMS roughness $(\mathrm{nm})$ & 5.73 & 3.94 & 2.83 & 1.01 & 0.61 & 0.25 \\
\hline
\end{tabular}

In order to access the adhesion between the $\mathrm{TiO}_{2}-\mathrm{SiO}_{2}(0.1 \%)$ film and clean glass, the standard test method (ASTM D3359) [33] was used by applying and removing pressuresensitive tape over cuts made in the film. The results showed that the adhesion forces of films prepared for all withdrawal speeds are ASTM class 5B, indicating no film pull-off and representing the highest level of adhesion.

\subsection{Rapid Plasma-Nitridation of Films by Different $\mathrm{N}_{2}$-Containing Gases}

The superior experimental conditions when preparing the high-adhesion, transparent, and superhydrophilic $\mathrm{TiO}_{2}-\mathrm{SiO}_{2}$ film on glass were achieved by adding $0.1 \mathrm{wt} . \%$ of $\mathrm{SiO}_{2}$ at a WS of $8 \mathrm{~mm} / \mathrm{s}$. However, the photocatalytic performance should be carried out under UV irradiation. To produce a visible photo-induced photocatalytic $\mathrm{TiO}_{2}-\mathrm{SiO}_{2}$ film, 
the prepared films were modified by doping $\mathrm{N}$ atoms via the rapid microwave plasmanitridation process in 1 min by inducing different $\mathrm{N}_{2}$-containing gases $\left(\mathrm{N}_{2}, \mathrm{~N}_{2} / \mathrm{Ar} / \mathrm{O}_{2}\right.$, $\mathrm{N}_{2} / \mathrm{Ar}$ ).

\subsubsection{Surface Composition Analyses}

The surface compositions and functional groups of the modified films were measured by XPS analysis. The results of chemical composition analysis showed that the content of $\mathrm{N}$ atoms was 1.3, 0.9 , and $0.1 \mathrm{wt}$. $\%$ in the $\mathrm{TiO}_{2}-\mathrm{SiO}_{2}$ film by using $\mathrm{N}_{2}, \mathrm{~N}_{2} / \mathrm{Ar} / \mathrm{O}_{2}$, and $\mathrm{N}_{2} / \mathrm{Ar}$ plasma gases, respectively, indicating that more $\mathrm{N}$ atoms could be doped by $\mathrm{N}_{2}$ plasma.

In Figure 6, the $\mathrm{N}_{1 \mathrm{~S}}$ peak regions were deconvoluted into surface functional group contributions. The peaks of $\mathrm{N}_{1 \mathrm{~s}}$ observed with the chemical bonding energies around 398.2 399.3 eV, 400.6 401.7 eV, 402.7 403.7 eV, 407.1 407.3 eV, and $409.1 \mathrm{eV}$ when using $\mathrm{N}_{2}$ or $\mathrm{N}_{2} / \mathrm{Ar} / \mathrm{O}_{2}$ gases indicate the possible presence of $\mathrm{N}-\mathrm{TiO}_{2}$ or $\mathrm{N}-\mathrm{O}$ bonds $\left(\mathrm{TiN}_{\mathrm{x}} \mathrm{O}_{\mathrm{y}}\right)$, adsorbed $\mathrm{N}_{2}$, TiO-N, $\mathrm{N}_{2} \mathrm{O}$ adsorption, and $\mathrm{NO}^{3-}$ (surface nitrate), respectively (Figure 6a,b) [34-37]. However, by using $\mathrm{N}_{2} / \mathrm{Ar}$ as plasma gases (Figure $6 \mathrm{c}$ ), it is similar to unmodified films (Figure $6 \mathrm{~d}$ ), lacking an apparent $\mathrm{N}$ peak region that can be deconvoluted into surface functional group contributions, which may be caused by the reduction in density of high energetic $\mathrm{N}$-containing species due to easier energy transfer to Ar than to $\mathrm{N}_{2}$ molecules in the discharge zone. The main functional groups for the plasma $\mathrm{N}$-doped films showed that $\mathrm{O}$ can be substituted rapidly for the $\mathrm{N}$ in $\mathrm{TiO}_{2}$ via the formation of oxygen vacancy [38] by using an atmospheric-pressure MW plasma coupled with plasma-nitridation gases.
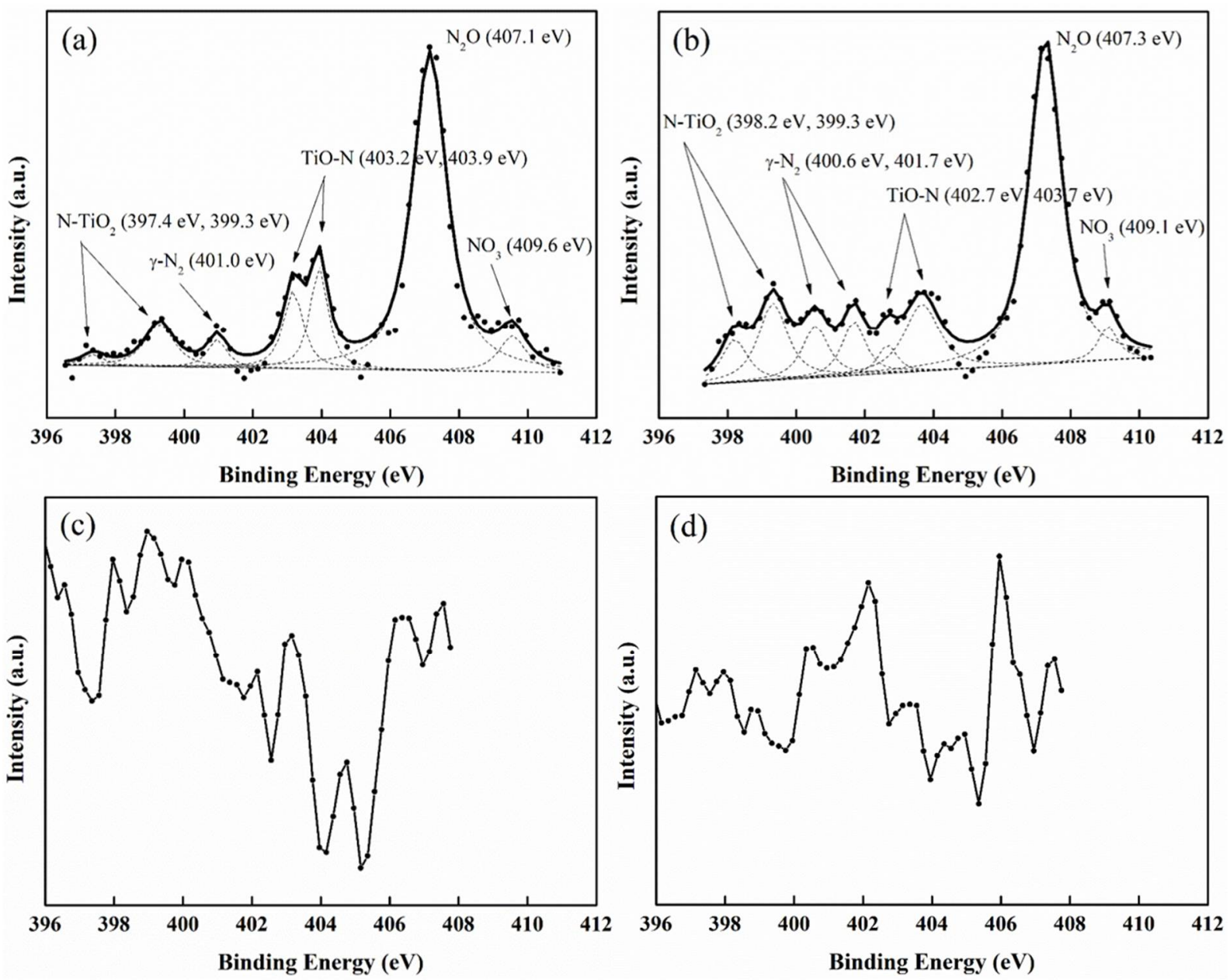

Figure 6. XPS spectra of $\mathrm{N}_{1 \mathrm{~s}}$ for as-prepared $\mathrm{SiO}_{2}-\mathrm{TiO}_{2}$ films modified by different plasma gases: (a) $\mathrm{N}_{2}$, (b) $\mathrm{N}_{2} / \mathrm{Ar} / \mathrm{O}_{2}$, (c) $\mathrm{N}_{2} / \mathrm{Ar}$, and (d) without nitridation (dots: measured XPS data; dashed lines: fittings of binding energy spectra to XPS data; solid lines: sum of the fitted data). 


\subsubsection{Photocatalytic Performance of As-Modified Films under Visible-Light Irradiation}

Under the condition of UV-light irradiation, the $\mathrm{TiO}_{2}-\mathrm{SiO}_{2}$ films will be superhydrophilic $\left(\theta<5^{\circ}\right)$. However, for utilization under a visible photo-induced environment, for example, indoors or a cloudy day, the superhydrophilic visible-induced $\mathrm{TiO}_{2}-\mathrm{SiO}_{2}$ $(0.1 \mathrm{wt} . \%)$ films on glass with high adhesion, transparent, and anti-fogging ability are prepared via the rapid ( $1 \mathrm{~min}$ ) plasma $\mathrm{N}$-doping process by different plasma gases, including $\mathrm{N}_{2}, \mathrm{~N}_{2} / \mathrm{Ar} / \mathrm{O}_{2}$, and $\mathrm{N}_{2} /$ Ar.

The analysis of UV-visible spectra of the non-doped and N-doped $\mathrm{TiO}_{2}-\mathrm{SiO}_{2}$ films (Figure 7) indicated that nitrogen plasma modification promoted visible-light absorption and red shift. The non-doped $\mathrm{TiO}_{2}-\mathrm{SiO}_{2}$ film shows the absorbance edge around $380 \mathrm{~nm}$. A red shift in the absorption edge toward the visible-light region ( $\lambda$ is about $410 \mathrm{~nm}$ ) is evident in the $\mathrm{N}$-doped $\mathrm{TiO}_{2}-\mathrm{SiO}_{2}$ film modified by $\mathrm{N}_{2}$ plasma at $0.9 \mathrm{~kW}$ for 1 min due to the incorporation of nitrogen atoms into the lattice of $\mathrm{TiO}_{2}$.

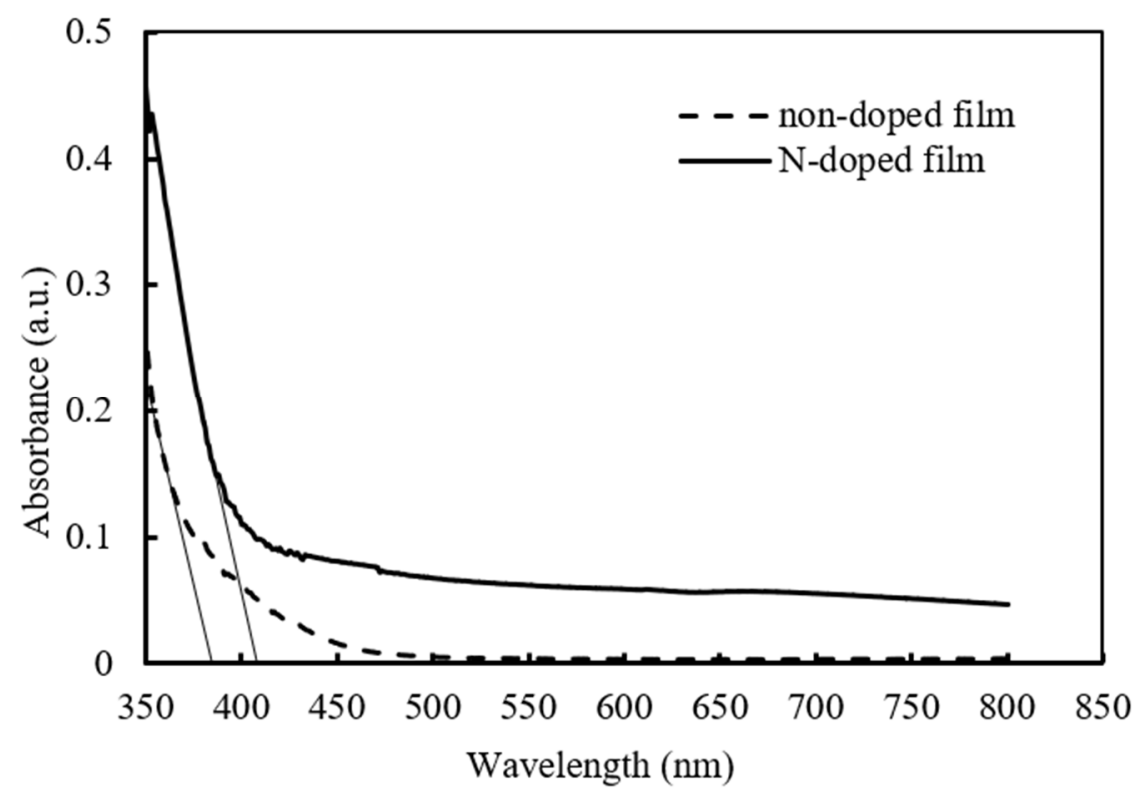

Figure 7. UV-vis absorption spectra of the non-doped and N-doped films.

The removal efficiency of methylene blue (MB) in a glass reactor was carried out using visible-light irradiation, to evaluate the performance of the individual $\mathrm{N}$-doped films [39]. The results of degradation for the photocatalytic activity of the $\mathrm{TiO}_{2}-\mathrm{SiO}_{2}$ (0.1 wt.\%) films modified by different plasma gases are compared in Figure 8. Under visible-light degradation, the orders of conversion of $\mathrm{MB}$ are the films modified by $\mathrm{N}_{2}$ $(84.3 \%)>\mathrm{N}_{2} / \mathrm{Ar} / \mathrm{O}_{2}>\mathrm{N}_{2} / \mathrm{Ar}>>$ without nitridation (14.8\%) after a visible-light irradiation of $500 \mathrm{~min}$, indicating that the photocatalytic performance of $\mathrm{TiO}_{2}-\mathrm{SiO}_{2}$ films modified by $\mathrm{N}_{2}$ plasma was slightly higher than that of those by $\mathrm{N}_{2} / \mathrm{Ar} / \mathrm{O}_{2}$ or $\mathrm{N}_{2} / \mathrm{Ar}$ plasma; however, this was much higher than that of those without $\mathrm{N}$-doped film.

The results revealed that a higher removal efficiency of methylene blue for visible-light induced degradation was found at a higher content of $\mathrm{N}$ atoms in $\mathrm{TiO}_{2}-\mathrm{SiO}_{2}$ film, because the red shift of $\mathrm{N}$-doped films into the visible light absorption range was achieved. The results also indicate that the plasma-nitridation process can be used for rapid N-doped modification of films. Moreover, the photocatalytic reaction of MB is usually fitted with the pseudo-first-order reaction rate under visible light irradiation [28]. 


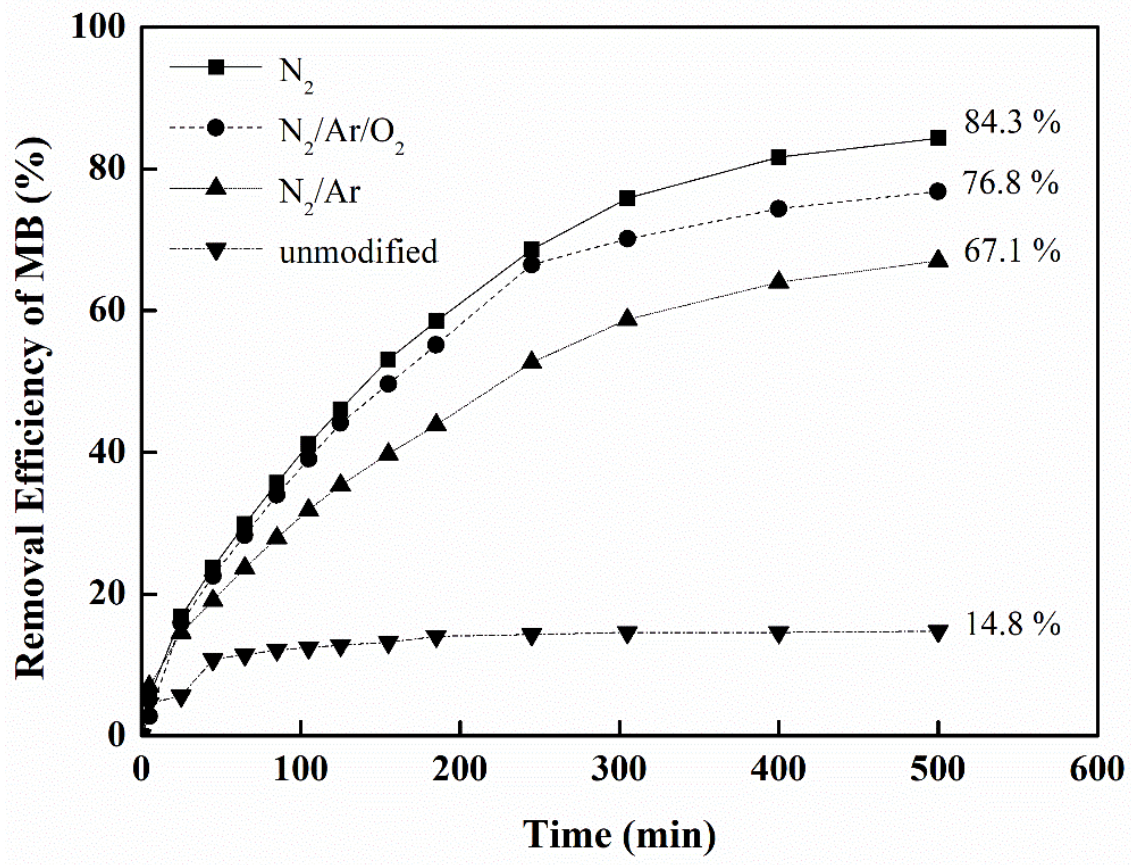

Figure 8. Photocatalytic conversion of methylene blue under visible-light irradiation for the $\mathrm{TiO}_{2}$ $\mathrm{SiO}_{2}(0.1 \mathrm{wt} . \%)$ films modified by different plasma gases $\left(\mathrm{N}_{2}, \mathrm{~N}_{2} / \mathrm{Ar} / \mathrm{O}_{2}, \mathrm{~N}_{2} / \mathrm{Ar}\right.$, unmodified) $(\mathrm{MB}=15 \mathrm{ppm}, \mathrm{MB}$ solution $=15 \mathrm{~mL})$.

\subsubsection{Characterization of Optical Emission Spectra}

An MW plasma can be successfully used to rapidly dope $\mathrm{N}$ atoms into $\mathrm{TiO}_{2}-\mathrm{SiO}_{2}$ films in $1 \mathrm{~min}$ of residence time. Resulting from active or energetic $\mathrm{N}$-containing species, including atomic $\mathrm{N}$, excited $\mathrm{N}_{2}, \mathrm{~N}$ ions, and $\mathrm{N}_{2}$ ions, are generated from nitrogen and ammonia gas in the glow discharge zone $[40,41]$. These energetic $\mathrm{N}$-containing species can thermodynamically react with $\mathrm{TiO}_{2}$ more easily than $\mathrm{N}_{2}$ molecules, forming $\mathrm{TiO}_{2-\mathrm{x}} \mathrm{N}_{\mathrm{x}}$.

Figure 9 shows the optical emission intensity of intermediate species that were detected in the glow discharge zone at $0.9 \mathrm{~kW}$. For nitrogen plasma, the active or energetic species can be produced via the complex plasma-chemical reactions, such as electronimpact processes, dissociative ionization, ionization, excitation reactions, and Penning ionization reaction. The characteristic emission lines of $\mathrm{N}_{2}$ from the first positive band $\left(B^{3} \Pi_{\mathrm{g}} \rightarrow \mathrm{A}^{3} \Sigma_{\mathrm{u}}{ }^{+}\right.$transition, at $\left.550-900 \mathrm{~nm}\right)$ and the second positive band $\left(\mathrm{C}^{3} \Pi_{\mathrm{u}} \rightarrow \mathrm{B}^{3} \Pi_{\mathrm{g}}\right.$ transition, at 300-400 nm), and the emission lines of $\mathrm{N}_{2}{ }^{+}$from the first negative band $\left(\mathrm{B}^{2} \Sigma_{\mathrm{u}}{ }^{+} \rightarrow \mathrm{X}^{2} \Sigma_{\mathrm{g}}{ }^{+}\right.$transition, at 381-470 nm) [40-42], and nearly all the peaks correspond to molecular nitrogen and ionic molecular nitrogen for $\mathrm{N}_{2}$ or $\mathrm{N}_{2}$ / Ar plasma gases (Figure 9) can be identified. However, the atomic nitrogen metastable molecule and ionic atomic nitrogen can not to be observed in the discharge zone. Moreover, weak representative optical emission spectra of Ar in the range of $700 \sim 850 \mathrm{~nm}$ can also be identified. Except for $\mathrm{N}_{2}$ or $\mathrm{N}$ band, Figure 9 also shows that $\mathrm{N}-\mathrm{O}$ bands ( $\gamma$ system, 226.9, 237.0, 247.9, 259.6, $272.2,286.0 \mathrm{~nm})$ and very weak $\mathrm{O}$ peaks $(777.2,777.4 \mathrm{~nm})$ can be observed in the $\mathrm{O}_{2}{ }^{-}$ containing $\left(\mathrm{N}_{2} / \mathrm{Ar} / \mathrm{O}_{2}\right)$ MW plasma $[43,44]$. 


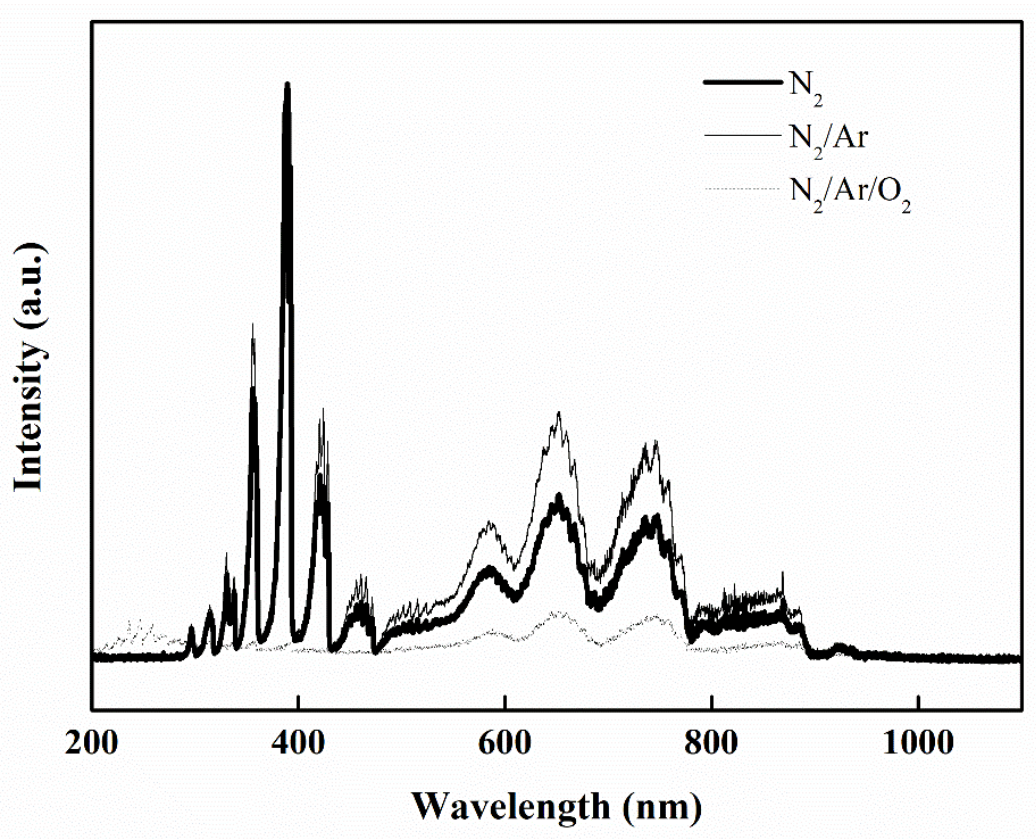

Figure 9. Optical emission spectra for plasma-nitridation by different gases $\left(\mathrm{N}_{2}, \mathrm{~N}_{2} / \mathrm{Ar}, \mathrm{N}_{2} / \mathrm{Ar} / \mathrm{O}_{2}\right)$ at 760 Torr, $0.9 \mathrm{~kW}$.

\subsection{Characteristics of $\mathrm{TiO}_{2}-\mathrm{SiO}_{2}$ Films after Plasma-Nitridation}

$\theta$ was about $10^{\circ}$ for the clean glass substrate, $7 \sim 18^{\circ}$ for $\mathrm{TiO}_{2}$ film/glass, $5 \sim 10^{\circ}$ for $\mathrm{TiO}_{2}-\mathrm{SiO}_{2}(0.1 \mathrm{wt} . \%)$ film/glass, and lower than $5^{\circ}$ after $\mathrm{UV}$ radiation of $20 \mathrm{~min}$ for $\mathrm{TiO}_{2}-$ $\mathrm{SiO}_{2}(0.1 \mathrm{wt.} \%)$ film. The $\mathrm{TiO}_{2}-\mathrm{SiO}_{2}(0.1 \mathrm{wt} . \%)$ film was prepared via modification by a rapid (1 min) microwave plasma-nitridation process using different $\mathrm{N}_{2}$-containing gases, resulting in $\theta$ being lower than $5^{\circ}$ without visible-light irradiation, as shown in Table 2. After the plasma-nitridation process, the regular, porous, and smooth surface was formed, leading to an increase in hydrophilicity [45]. Moreover, $\theta$ was still decreased to about $3^{\circ}$ after visible-light irradiation for $20 \mathrm{~min}$, regardless of what kind of plasma gases were utilized (Table 3), revealing that the modified superhydrophilic and anti-fogging films could be used in a visible photo-induced environment.

Table 3. Contact angle $(\theta)$ for different $\mathrm{N}$-containing gases after various visible-light irradiation times (min) by MW plasma for $\mathrm{TiO}_{2}-\mathrm{SiO}_{2}(0.1 \%)$ films.

\begin{tabular}{ccccc}
\hline Irradiation Time (min) & $\mathbf{0}$ & $\mathbf{5}$ & $\mathbf{1 0}$ & $\mathbf{2 0}$ \\
\hline Plasma Gases & \multicolumn{4}{c}{ Contact Angle $(\theta)$} \\
$\mathrm{N}_{2}$ & 3.7 & 3.6 & 3.2 & 3.1 \\
$\mathrm{~N}_{2} / \mathrm{Ar} / \mathrm{O}_{2}$ & 3.8 & 3.6 & 3.4 & 3.3 \\
$\mathrm{~N}_{2} / \mathrm{Ar}$ & 3.9 & 3.8 & 3.5 & 3.3 \\
\hline
\end{tabular}

After the plasma-nitridation process, the RMS roughness of the film surface slightly decreased when compared to that without plasma-nitridation, from $3.94 \mathrm{~nm}$ (unmodified) to $3.54 \mathrm{~nm}\left(\mathrm{~N}_{2}\right.$ plasma), $3.50 \mathrm{~nm}\left(\mathrm{~N}_{2} / \mathrm{Ar} / \mathrm{O}_{2}\right.$ plasma), and $3.29 \mathrm{~nm}\left(\mathrm{~N}_{2} / \mathrm{Ar}\right)$ (Table 3). Hence, the RMS roughness of films was not affected significantly by plasma-nitridation. Visible-light transmittance was also unchanged by the different plasma gases, more so than that of the unmodified $\mathrm{TiO}_{2}-\mathrm{SiO}_{2}$ film or clean glass, reaching a range of $89.8 \sim 90.1 \%$ (Table 3). Both the film being modified at low temperature $\left(500^{\circ} \mathrm{C}\right)$ and a short modification time (1 $\mathrm{min})$ resulted in the roughness not being significantly changed, and the film surface was porous and smooth with a high visible-light transmittance.

In order to assess the hardness of the $\mathrm{TiO}_{2}-\mathrm{SiO}_{2}(0.1 \%)$ film on the glass, the standard test method (ASTM D3363-05) [46] was carried out by drawing with pencil leads of known 
hardness. This ranges from $9 \mathrm{H}$ (hardest), $8 \mathrm{H}, 7 \mathrm{H}, \ldots 7 \mathrm{~B}, 8 \mathrm{~B}$ to $9 \mathrm{~B}$ (softest). The results showed that the pencil hardness of all prepared films for various plasma nitridation gases was $7 \mathrm{H}$ (Table 4), indicating good sol-gel coatings on glass $(9 \mathrm{H})$ due to the in situ prepared nanoparticles with only $0.1 \% \mathrm{SiO}_{2}$ nanoparticles due to the nature of networking [47].

Table 4. Characteristics of $\mathrm{TiO}_{2}-\mathrm{SiO}_{2}(0.1 \%)$ films after plasma-nitridation modified by various plasma gases (withdrawal speed $=8 \mathrm{~mm} / \mathrm{s}$ ).

\begin{tabular}{cccccc}
\hline Plasma Gases & Unmodified & $\mathbf{N}_{\mathbf{2}}$ & $\mathbf{N}_{\mathbf{2}} / \mathbf{A r} / \mathbf{O}_{\mathbf{2}}$ & $\mathbf{N}_{\mathbf{2}} / \mathbf{A r}$ & Clean Glass \\
\hline RMS roughness $(\mathrm{nm})$ & 3.94 & 3.54 & 3.50 & 3.29 & 0.25 \\
Average & 89.7 & 90.1 & 89.8 & 90.0 & 90.5 \\
transmittance (\%) & $7 \mathrm{H}$ & $7 \mathrm{H}$ & $7 \mathrm{H}$ & $7 \mathrm{H}$ & $9 \mathrm{H}$ \\
Film hardness & & &
\end{tabular}

\section{Conclusions}

This study successfully developed procedures to optimize the operational conditions for the sol-gel dip-coating method combined with a rapid plasma-nitridation technique to produce $\mathrm{N}$-doped $\mathrm{TiO}_{2}-\mathrm{SiO}_{2}$ nano film on glass, while simultaneously achieving a high transmittance $(\sim 90 \%)$, high hardness $(7 \mathrm{H})$, superhydrophilicity $\left(\theta<5^{\circ}\right)$, and good adhesion (5B) for the applications of self-cleaning and anti-fogging. Moreover, the high photocatalytic performance of the film/glass can be easily accomplished under visible photo-induced irradiation after the rapid plasma-nitridation process.

Author Contributions: B.-J.L.: investigation, formal analysis, validation, writing-review and editing; K.-T.L.: conceptualization, formal analysis, writing-review and editing; Y.-M.K.: resources, supervision, project administration, writing - review and editing; C.-H.T.: investigation, visualization, data curation, methodology, writing-original draft. All authors have read and agreed to the published version of the manuscript.

Funding: We would like to thank the Ministry of Science and Technology of Taiwan for its financial support under grants MOST 107-2221-E-992-003 and MOST 107-2622-E-992-017-CC3.

Institutional Review Board Statement: Not applicable.

Informed Consent Statement: Not applicable.

Data Availability Statement: Data is contained within the article.

Acknowledgments: The authors gratefully acknowledge the use of EM000600 and EM000600 of MOST 108-2731-M-006-001 belonging to the Core Facility Center of National Cheng Kung University.

Conflicts of Interest: The authors declare no conflict of interest.

\section{References}

1. Bolis, V.; Busco, C.; Ciarletta, M.; Distasi, C.; Erriquez, J.; Fenoglio, I.; Livraghi, S.; Morel, S. Hydrophilic/hydrophobic features of $\mathrm{TiO}_{2}$ nanoparticles as a function of crystal phase, surface area and coating, in relation to their potential toxicity in peripheral nervous system. J. Colloid Interface Sci. 2012, 369, 28-39. [CrossRef]

2. Chen, X.; Mao, S.S. Titanium dioxide nanomaterials: Synthesis, properties, modifications, and applications. Chem. Rev. 2007, 107, 2891-2959. [CrossRef] [PubMed]

3. Nazeeruddin, M.K.; Baranoff, E.; Gratzel, M. Dye-sensitized solar cells: A brief overview. Sol. Energy 2011, 85, 1172-1178. [CrossRef]

4. $\quad$ de Jesus, M.A.M.L.; Neto, J.T.d.S.; Timò, G.; Paiva, P.R.P.; Dantas, M.S.S.; Ferreira, A.d.M. Superhydrophilic self-cleaning surfaces based on $\mathrm{TiO}_{2}$ and $\mathrm{TiO}_{2} / \mathrm{SiO}_{2}$ composite films for photovoltaic module cover glass. Appl. Adhes. Sci. 2015, 3, 5. [CrossRef]

5. Kameya, Y.; Yabe, H. Optical and superhydrophilic characteristics of $\mathrm{TiO}_{2}$ coating with subwavelength surface structure consisting of spherical nanoparticle aggregates. Coatings 2019, 9, 547. [CrossRef]

6. Lai, Y.; Tang, Y.; Gong, J.; Gong, D.; Chi, L.; Lin, C.; Chen, Z. Transparent superhydrophobic/superhydrophilic TiO 2 -based coatings for self-cleaning and anti-fogging. J. Mater. Chem. 2012, 22, 74209-77426. [CrossRef]

7. Chen, T.L.; Hirose, Y.; Hitosugi, T.; Hasegawa, T. One unit-cell seed layer induced epitaxial growth of heavily nitrogen doped anatase $\mathrm{TiO}_{2}$ films. J. Phys. D Appl. Phys. 2008, 41, 062005. [CrossRef] 
8. Wang, Y.; Wu, P.; Li, B.; Zhu, N.; Dang, Z. In-depth study on intercalating threonine into layered double hydroxides. Appl. Clay Sci. 2011, 53, 615-620. [CrossRef]

9. Lin, Y.S.; Lien, S.Y.; Wuu, D.S.; Huang, Y.X.; Kung, C.Y. Improvement in performance of Si-based thin film solar cells with a nanocrystalline $\mathrm{SiO}_{2}-\mathrm{TiO}_{2}$ layer. Thin Solid Films 2014, 570, 200-203. [CrossRef]

10. Arin, M.; Watté, J.; Pollefeyt, G.; Buysser, K.D.; Driessche, I.V.; Lommens, P. Low temperature deposition of TiO 2 layers from nanoparticle containing suspensions synthesized by microwave hydrothermal treatment. J. Sol. Gel Sci. Technol. 2013, 66, 100-111. [CrossRef]

11. Parkin, P.; Palgrave, R.G. Self-cleaning coatings. J. Mater. Chem. 2005, 15, 1689-1695. [CrossRef]

12. Daghrir, R.; Drogui, P.; Robert, D. Modified $\mathrm{TiO}_{2}$ for environmental photocatalytic applications: A review. Ind. Eng. Chem. Res. 2013, 52, 3581-3599. [CrossRef]

13. Kumar, S.G.; Devi, L.G. Review on modified $\mathrm{TiO}_{2}$ photocatalysis under UV/Visible light: Selected results and related mechanisms on interfacial charge carrier transfer dynamics. J. Phys. Chem. A 2011, 115, 13211-13241. [CrossRef]

14. Rampaul, A.; Parkin, I.P.; O’Neill, S.A.; DeSouza, J.; Mills, A.; Elliott, N. Titania and tungsten doped titania thin films on glass; active photocatalysts. Polyhedron 2003, 22, 35-44. [CrossRef]

15. Seery, M.K.; George, R.; Floris, P.; Pillai, S.C. Silver doped titanium dioxide nanomaterials for enhanced visible light photocatalysis. J. Photochem. Photobiol. A 2007, 189, 258-263. [CrossRef]

16. Tian, $\mathrm{H} . ; \mathrm{Ma}$, J.; Li, K.; $\mathrm{Li}$, J. Hydrothermal synthesis of S-doped $\mathrm{TiO}_{2}$ nanoparticles and their photocatalytic ability for degradation of methyl orange. Ceram. Int. 2009, 35, 1289-1292. [CrossRef]

17. Bakara, A.B.; Ribeiro, C. Nitrogen-doped titanium dioxide: An overview of material design and dimensionality effect over modern applications. J. Photochem. Photobiol. C 2016, 27, 1-29. [CrossRef]

18. Sato, S.; Nakamura, R.; Abe, S. Visible-light sensitization of $\mathrm{TiO}_{2}$ photocatalysts by wet-method N doping. Appl. Catal. A 2005, 284, 131-137. [CrossRef]

19. Wawrzyniak, B.; Morawski, A.W. Solar-light-induced photocatalytic decomposition of two azo dyes on new $\mathrm{TiO}_{2}$ photocatalyst containing nitrogen. Appl. Catal. B 2006, 62, 150-158. [CrossRef]

20. Ansari, S.A.; Khan, M.M.; Ansari, M.O.; Cho, M.H. Nitrogen-doped titanium dioxide $\left(\mathrm{N}-\right.$ doped $\left.\mathrm{TiO}_{2}\right)$ for visible light photocatalysis. New J. Chem. 2016, 40, 3000-3009. [CrossRef]

21. Nosaka, Y.; Matsushita, M.; Nasino, J.; Nosaka, A.Y. Nitrogen-doped titanium dioxide photocatalysts for visible response prepared by using organic compounds. Sci. Technol. Adv. Mater. 2005, 6, 143-148. [CrossRef]

22. Chekini, M.; Mohammadizadeh, M.R.; Allaei, S.M.V. Photocatalytic and superhydrophilicity properties of $\mathrm{N}^{-\mathrm{dop}} \mathrm{ped}$ TiO 2 nano thin films. Appl. Surf. Sci. 2011, 257, 7179-7183. [CrossRef]

23. Mechiakh, R.; Sedrine, N.B.; Chtourou, R.; Bensaha, R. Correlation between microstructure and optical properties of nanocrystalline $\mathrm{TiO}_{2}$ thin films prepared by sol-gel dip coating. Appl. Surf. Sci. 2010, 257, 670-676. [CrossRef]

24. Oh, S.H.; Kim, D.J.; Hahn, S.H.; Kim, E.J. Comparison of optical and photocatalytic properties of $\mathrm{TiO}_{2}$ thin films prepared by electron-beam evaporation and sol-gel dip-coating. Mater. Lett. 2003, 57, 4151-4155. [CrossRef]

25. Tajima, K.; Yamada, Y.; Bao, S.; Okada, M.; Yoshimura, K. Solid electrolyte of tantalum oxide thin film deposited by reactive DC and RF magnetron sputtering for all-solid-state switchable mirror gass. Sol. Energy Mater. Sol. Cells 2008, 92, 120-125. [CrossRef]

26. Yamada, K.; Yamane, H.; Matsushima, S.; Nakamura, H.; Sonoda, T.; Miura, S.; Kumada, K. Photocatalytic activity of TiO 2 thin films doped with nitrogen using a cathodic magnetron plasma treatment. Thin Solid Films 2008, 516, 7560-7564. [CrossRef]

27. Lin, J.; Ma, D.; Li, Y.; Zhang, P.; Mi, H.; Deng, L.; Sun, L.; Ren, X. In situ nitrogen doping of $\mathrm{TiO}_{2}$ by plasma enhanced atomic layer deposition for enhanced sodium storage performance. Dalton Trans. 2017, 46, 13101-13107. [CrossRef] [PubMed]

28. Lai, Y.C.; Wang, Y.F.; Tsai, Y.I.; Tsai, C.H. A simple process for synthesizing nano Pt- and/or N-doped titanium dioxide powders by microwave plasma torch. J. Alloys Compd. 2014, 617, 834-840. [CrossRef]

29. Zhang, X.T.; Sato, O.; Taguchi, M.; Einaga, Y.; Murakami, T.; Fujishima, A. Self-cleaning particle coating with antireflection properties. Chem. Mater. 2005, 17, 696-700. [CrossRef]

30. Pandiyaraj, K.N.; Selvarajan, V.; Pavese, M.; Falaras, P.; Tsoukleris, D. Investigation on surface properties of TiO $\mathrm{T}_{2}$ films modified by DC glow discharge plasma. Curr. Appl. Phys. 2009, 9, 1032-1037. [CrossRef]

31. Machida, M.; Norimoto, K.; Watanabe, T.; Hashimoto, K.; Fujishima, A. The effect of $\mathrm{SiO}_{2}$ addition in super-hydrophilic property of $\mathrm{TiO}_{2}$ photocatalyst. J. Mater. Sci. 1999, 34, 2569-2574. [CrossRef]

32. Chen, D. Anti-refection (AR) coatings made by sol-gel processes: A review. Sol. Energy Mater. Sol. Cells 2001, 68, 313-336. [CrossRef]

33. ASTM D3359-02 Standard Test Methods for Measuring Adhesion by Tape Test; ASTM International: West Conshohocken, PA, USA, 2004.

34. Baltrusaitis, J.; Jayaweera, P.M.; Grassian, V.H. XPS study of nitrogen dioxide adsorption on metal oxide particle surfaces under different environmental conditions. Phys. Chem. Chem. Phys. 2009, 11, 8295-8305. [CrossRef]

35. Chen, C.; Bai, H.; Chang, C. Effect of plasma processing gas composition on the nitrogen-doping status and visible light photocatalysis of $\mathrm{TiO}_{2}$. J. Phys. Chem. C 2007, 111, 15228-15235. [CrossRef]

36. Jain, N.; Paul, A.K.; Srivastava, T.S. Synthesis, characterization, cytotoxicity and DNA binding studies of diamminediethyldithiocarbamato-platinum(II) nitrate. J. Inorg. Biochem. 1992, 45, 123-127. [CrossRef] 
37. Pashutski, A.; Folman, M. Low temperature XPS studies of $\mathrm{NO}$ and $\mathrm{N}_{2} \mathrm{O}$ adsorption on $\mathrm{Al}(100)$. Surf. Sci. 1989, 216, 395-408. [CrossRef]

38. Huang, C.M.; Chen, L.C.; Cheng, K.W.; Pan, G.T. Effect of nitrogen-plasma surface treatment to the enhancement of TiO 2 photocatalytic activity under visible light irradiation. J. Mol. Catal. A Chem. 2007, 261, 218-224. [CrossRef]

39. Kim, C.; Choi, M.; Jang, J. Nitrogen-doped $\mathrm{SiO}_{2} / \mathrm{TiO}_{2}$ core/shell nanoparticles as highly efficient visible light photocatalyst. Catal. Commun. 2010, 11, 378-382. [CrossRef]

40. Hsueh, H.P.; McGrath, R.T.; Ji, B.; Felker, B.S.; Langan, J.G.; Karwacki, E.J. Ion energy distribution and optical emission spectra in $\mathrm{NF}_{3}$-based process chamber plasma. J. Vac. Sci. Technol. B Microelectron. Nanometer Struct. 2001, 19, 1346-1357. [CrossRef]

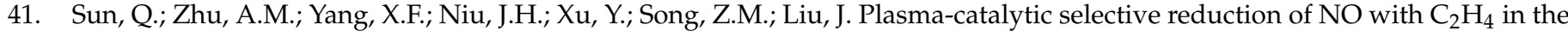
presence of excess oxygen. Chin. Chem. Lett. 2005, 16, 839-842.

42. Jeong, B.Y.; Kim, M.H. Effects of the process parameters on the layer formation behavior of plasma nitrided steels. Surf. Coat. Technol. 2001, 141, 182-186. [CrossRef]

43. Goujon, M.; Belmonte, T.; Henrion, G. OES and FTIR diagnostics of $\mathrm{HMDSO} / \mathrm{O}_{2}$ gas mixture for $\mathrm{SiO}_{\mathrm{x}}$ deposition assisted by RF plasma. Surf. Coat. Technol. 2004, 188-189. [CrossRef]

44. Timmermans, E.A.H.; Jonkers, J.; Rodero, A.; Quintero, M.C.; Sola, A.; Gamero, A.; Schram, D.C.; van der Mullen, J.A.M. The behavior of molecules in microwave-induced plasma studies by optical emission spectroscopy. 2: Plasma at reduced pressure. Spectrochim. Acta B 1999, 54, 1085-1098. [CrossRef]

45. Hashimoto, K.; Irie, H.; Fujishima, A. $\mathrm{TiO}_{2}$ Photocatalysis: A historical overview and future prospects. Jpn. J. Appl. Phys. 2005, 44, 8269-8285. [CrossRef]

46. ASTM D3363-05 Standard Test Method for Film Hardness by Pencil Test; ASTM International: West Conshohocken, PA, USA, 2011.

47. Kalidindi, R.S.R.; Subasri, R. Sol-gel nanocomposite hard coatings, anti-abrasive nanocoatings. Curr. Future Appl. 2015, 105-136. [CrossRef] 